\title{
Isolation and Culture of Alveolar Epithelial Type I and Type II Cells from Rat Lungs
}

\author{
Robert F. Gonzalez and Leland G. Dobbs
}

\section{Abstract}

The pulmonary alveolar epithelium, comprised of alveolar Type I (TI) and Type II (TII) cells, covers more than $99 \%$ of the internal surface area of the lungs. The study of isolated and cultured alveolar epithelial TI and TII cells has provided a large amount of information about the functions of both cell types. This chapter provides information about methods for isolating and culturing both of these cell types from rat lungs.

\section{Keywords}

Lung; Alveolar epithelium; Type I cells; Type II cells

\section{Introduction}

More than $99 \%$ of the internal surface area of the lung is contained within the alveolar compartment (1) which is lined by two types of cells, Type I (TI) and Type II (TII) cells. Type I cells comprise $\sim 8 \%$ of the cells in the lung, but cover $\sim 95-98 \%$ of the surface area; TII cells comprise $\sim 14 \%$ of all lung cells and cover the remaining $\sim 2-5 \%$ of the internal surface area (2). TI cells are very large squamous cells (calculated diam. $\sim 50-100 \mu \mathrm{m}$ ) whose thin $(50-100 \mathrm{~nm})$ cytoplasmic extensions form the epithelial portion of the air-blood barrier essential for normal gas exchange; TI cells participate in ion and fluid transport (3) and are likely to have other important functions within the lung (4). In vitro, TI cells have the capacity to proliferate (5). TII cells are smaller (diam. $\sim 10 \mu \mathrm{m}$ ), cuboidal cells that synthesize, secrete, and recycle surfactant components, transport ions, participate in lung immune responses, and in vivo function as progenitor cells in response to injury.

There have been many attempts to establish passaged cell lines as models of both cell types. Unfortunately, these cell lines have been disappointing because none display the full range of morphologic, biochemical, and molecular characteristics of freshly isolated TI or TII cells. Although the primary culture of epithelial cells has disadvantages in that it involves repeated cell isolations and in that cells undergo different extents of phenotypic drift in culture, much has been learned from the study of primary cultures of both TI and TII cells. We have previously published a detailed method for the isolation of TII cells from rat lungs using the "panning method" to purify cells using IgG-coated plates (6-8). In this communication, we focus on methods using TI or TII cell-specific antibodies to isolate these cell types from rat lungs. 


\section{Materials}

\subsection{Isolation of $\mathrm{TI}$ and $\mathrm{TII}$ Cells}

1. Specific-pathogen-free Sprague-Dawley rats, 100-150g (Charles River ${ }^{\mathrm{TM}}$ ).

2. Heparin $(1,000 \mathrm{U} / \mathrm{mL})$ and sodium pentobarbital $50 \mathrm{mg} / \mathrm{mL}$.

3. Suture: Size 3-0, silk.

4. Scissors, Mayo-Noble (6.5 in.) and microdissecting (4 in.).

5. Luer Stub Adaptor, 15 gauge (Intramedic ${ }^{\circledR}$, Becton Dickinson) (for tracheal cannulation).

6. Angiocath, 20 gauge plastic catheter, connected to the perfusion device containing Dulbecco's phosphate-buffered saline (DPBS).

7. DPBS.

8. Perfusion device constructed from a $50 \mathrm{~mL}$ disposable syringe with the plunger removed and $24 \mathrm{in}$. of plastic tubing attached to the end.

9. Disposable plastic syringes $(3,10,20$, and $50 \mathrm{~mL})$.

10. Ca-Mg-free DPBS containing $5 \mathrm{mM}$ EGTA and 5 mM EDTA.

11. "Solution A": RPMI 1640-HEPES medium (Gibco/BRL ${ }^{\mathrm{TM}}$ ).

12. "Solution B": For TI cell isolations use $40 \mathrm{~mL}$ "Solution A" containing $1.75 \mathrm{mg}$ elastase/mL (Worthington ${ }^{\circledR}$ ) and 10\% dextran (35-45,000 MW, Sigma-Aldrich ${ }^{\circledR}$ ).

13. "Solution C": For TII cell isolations use $40 \mathrm{~mL}$ "Solution A" containing $1 \mathrm{mg}$ elastase/mL (Worthington).

14. Tissue culture centrifuge tubes ( 15 and $50 \mathrm{~mL}$ sizes), disposable plastic beakers (500 and $50 \mathrm{~mL}$ sizes), and $250 \mathrm{~mL}$ disposable plastic Erlenmeyer flasks.

15. Fetal Bovine Serum (Hyclone ${ }^{\mathrm{TM}}$, Thermo Fisher Scientific).

16. DNAse (Sigma-Aldrich $\left.{ }^{\circledR}\right) 2 \mathrm{mg} / \mathrm{mL}$ "Solution A."

17. Rat IgG and mouse IgG (Sigma-Aldrich ${ }^{\circledR}$ ).

18. Filtering tubes made from plastic syringes $(10 \mathrm{~mL}$ and $20 \mathrm{~mL}$ capacity syringes with the end of the bore and the tips cut off so that the bore is of uniform diameter) with 20,40 , or $100 \mu \mathrm{m}$ nylon mesh filters (Tetko Inc. ${ }^{\circledR}$ ) secured at the cutoff ends with rubber bands. Make at least two with the $100 \mu \mathrm{m}$ filter, and 3-5 each with the $40 \mu \mathrm{m}$ and $20 \mu \mathrm{m}$ nylon mesh filters.

19. Fluorescein diacetate (FDA) (Sigma-Aldrich ${ }^{\circledR}$ ) $2 \mathrm{mg} / \mathrm{mL}$ acetone.

20. Percoll $^{\mathrm{TM}}$ (Life Technologies ${ }^{\mathrm{TM}}$ ).

21. Monoclonal antibody against RTI-40 (available from: http:// www.lungantibodyinfo.com).

22. Monoclonal antibody against RTII-70 (available from: http:// www.lungantibodyinfo.com).

23. Rat anti-mouse IgG1-, goat anti-mouse IgG-, and goat anti-rat IgG-ferromagnetic beads (Miltenyi Biotec).

24. Two types of capture columns were prepared from $3 \mathrm{~mL}$ disposable plastic syringes, one with $0.8 \mathrm{~g}$ of loosely packed "coarse grade" steel wool (\#3 grade) and 
one with $0.5 \mathrm{~g}$ of loosely packed "fine grade" steel wool (\#00 grade) (Homax ${ }^{\circledR}$ Products Inc.). Columns are gas sterilized.

25. Three-way Luer stopcocks.

26. Twenty three gauge hypodermic needles.

27. Capture magnet for cell isolation (VarioMACS ${ }^{\mathrm{TM}}$, Miltenyi Biotec).

28. Nine inch glass Pasteur Pipets.

\subsection{FACS Sorting and Assessing Purities of $\mathrm{TI}$ and TII Cell Populations After Isolation}

1. Monoclonal antibodies against RTI-40 and RTII-70 (see Subheading 2.1, items 21 and 22).

2. Zenon anti-mouse IgG1 Alexa Fluor ${ }^{\circledR}$ 610-RPE labeling kit (Life Technologies ${ }^{\mathrm{TM}}$ / Molecular Probes ${ }^{\circledR}$ ).

3. Antibodies against aquaporin-5 (AQP-5, Alpha Diagnostic) and pro-surfactant protein SP-C (pro-SP-C, Chemicon International ${ }^{\circledR}$ ).

4. Secondary antibodies specific for either mouse IgG3 or IgG1 labeled with Alexa Fluor $^{\circledR} 488$ or Alexa Fluor ${ }^{\circledR} 594$ (Life Technologies ${ }^{\mathrm{TM}}$ ).

5. BD FACS Aria Flow Cytometer (BD Biosciences ${ }^{\mathrm{TM}}$ ) or equivalent Flow Cytometer.

6. Cytocentrifuge.

7. Superfrost/Plus Microscope Slides, pre-cleaned.

8. $4 \%$ Paraformaldehyde (Sigma-Aldrich ${ }^{\circledR}$ ) made fresh in DPBS.

9. "Prolong" anti-fade reagent (Life Technologies ${ }^{\mathrm{TM}} /$ Molecular Probes ${ }^{\circledR}$ ).

10. Trypan Blue.

\subsection{Culture of TI Cells}

1. TI cell culture medium: Dulbecco's modified Eagle's medium H-16 (DME-H16) (Gibco/BRL ${ }^{\mathrm{TM}}$ ) containing $20 \% \mathrm{FBS}$ and $50 \mu \mathrm{g}$ gentamicin $/ \mathrm{mL}$.

2. Tissue culture 6-well Transwell ${ }^{\circledR}$ plates (Corning) previously coated with bovine fibronectin (see Subheading 3.3, step 2).

3. Syringe filter $(0.2 \mu \mathrm{m}$ syringe filter $)$.

\subsection{Culture of TII Cells}

1. TII cell culture medium: Dulbecco's modified Eagle's medium (DMEM) (Gibco/ $\mathrm{BRL}^{\mathrm{TM}}$ ) containing $1 \%$ rat serum, $10 \mathrm{ng} / \mathrm{mL}$ keratinocyte growth factor (KGF, FGF-7, R\&D Systems ${ }^{\circledR}$ ), $10^{-4}$ M 8-bromocyclic AMP (Sigma-Aldrich ${ }^{\circledR}$ ), and 50 $\mu \mathrm{g}$ gentamicin $/ \mathrm{mL}$.

2. Engelbreth-Holmes-Swarm Matrix (EHS Matrix, Matrigel ${ }^{\mathrm{TM}}, \mathrm{BD}^{\mathrm{TM}}$ ).

3. Tissue culture 6-well Transwell ${ }^{\circledR}$ plates (Corning) previously coated with EHS Matrix (see Subheading 3.4, step 2).

\section{Methods}

Alveolar epithelial cells are fragile and are easily injured (see Fig. 1). The keys to successful isolation and culture are rapid isolation (the entire procedure should take $<4.0 \mathrm{~h}$ ) while handling tissues and cells gently. Two indices of cell health are viability indices (>95\%) and 
plating efficiency (>70\% at $24 \mathrm{~h}$ ). Although both TI and TII cell types comprise relatively small percentages of all lung cells [TI, 9\%; TII, 14\% (from ref. 2)], enzymatic digestion of the lung with carefully timed intratracheal instillation of elastase provides an initial cell enrichment because elastase effectively liberates epithelial cells from the underlying basement membrane, leaving most of the interstitial and vascular compartments intact (9).

\subsection{Perfusion of the Lungs and Digestion of Lungs with Elastase}

1. Anesthetize the rat with an i.p. injection of pentobarbital (50 mg/kg/body weight) and heparin (400 U/kg/body weight). After the rat is well anesthetized, it is important to perform the following surgical procedures rapidly. The entire surgical procedure, from the time of the abdominal incision to removal of the perfused lungs, should take no more than 4 min.

2. Make an abdominal incision, cut the descending aorta, and make a small incision in the diaphragm to deflate the lungs.

3. Incise the neck, remove the submandibular tissue and the thyroid gland, pass a suture under the trachea, nick the trachea, and cannulate it with a 15 gauge Intramedic ${ }^{\circledR}$ Luer Stub Adaptor, securing it with the suture.

4. Incise the chest wall along the entire length of the sternum and the anterior portions of the diaphragm so that the chest is open.

5. Pull the rib cage laterally and horizontally to expose the heart and the lungs. The sharp cut edges of the ribs should not be close to the lungs, once they are inflated in subsequent steps.

6. Identify the pulmonary artery, pass a suture underneath it, nick the inferior portion of the right ventricle, and cannulate the pulmonary artery with a 20 gauge plastic catheter (occluding the puncture site) connected to a perfusion bottle containing DPBS at $20 \mathrm{~cm} \mathrm{H}_{2} \mathrm{O}$ pressure. The perfusion buffer and length of tubing should be free of any bubbles prior to starting the perfusion, because bubbles will lodge in the pulmonary capillary bed, obstructing perfusion.

7. Nick the left atrium to allow the perfusion fluid to exit the lungs.

8. During perfusion, gently inflate the lungs several times to total lung capacity (7-10 $\mathrm{mL}$ ) using a $10 \mathrm{~mL}$ syringe several times; this will expand the lung and allow perfusion to clear the lungs completely of blood. The heart should still be spontaneously beating during this step; if the heart is not spontaneously beating, it will be difficult to clear blood from the lungs. Following successful perfusion, the lungs should be completely white; there should not be red or pink areas.

9. Carefully remove the lungs, trachea (leaving the trachea still attached to the cannula), and heart from the chest cavity. Trim off and discard the heart.

10. Using the tracheal cannula to instil liquid, sequentially lavage the lungs to total lung capacity with $\mathrm{Ca}-\mathrm{Mg}$-free DPBS containing EGTA/EDTA (see Subheading 2.1 , item 10 ) at $37^{\circ} \mathrm{C}$ to remove macrophages. Lavage gently so that the lung integrity is maintained and the lungs do not become leaky.

11. Lavage once with "Solution A" (see Subheading 2.1, item 11) to total lung capacity and let the lungs drain with gravity. Lavage once more using "Solution B" (see Subheading 2.1, item 12) for TI cells or "Solution C" (see Subheading 2.1, item 13) for TII cells. Be careful not to overinflate the lungs, which may create a leak.

12. Inflate the lungs to total lung capacity with "Solution B" (TI cells) or "Solution C" (TII cells) while the lungs are suspended in a beaker of saline in a $37^{\circ} \mathrm{C}$ water bath; 
then suspend the enzyme-filled lungs so that they float in the warm saline while additional enzyme is gradually instilled. We use a $3 \mathrm{~mL}$ plastic syringe taped to the side of the beaker and gradually add the remaining elastase-containing solution by gravity over a 15-min period, for a total enzymatic digestion period of $20 \mathrm{~min}$ for TII cells. For TI cell isolation, the time of enzymatic digestion is $40 \mathrm{~min}$.

13. Dissect the lung parenchyma away from the major airways (do not spend the time to do this meticulously) and add the lungs to a $50 \mathrm{~mL}$ disposable plastic beaker containing $20 \mathrm{~mL}$ of fetal bovine serum (FBS) at $4{ }^{\circ} \mathrm{C}$ and $0.5 \mathrm{~mL}$ of DNAse solution (see Subheading 2.1, item 16).

14. Quickly mince the lung pieces with very sharp Mayo-Noble scissors to a final size of $\sim 1 \mathrm{~mm}^{3}$ ( 150-200 scissor strokes, duration <1 min).

15. Add additional "Solution A" to bring the final liquid volume to $30 \mathrm{~mL}$ and transfer the lung minces and liquid to a $250 \mathrm{~mL}$ plastic Erlenmeyer flask. Add rat IgG to a final concentration of $50 \mu \mathrm{g} / \mathrm{mL}$.

16. Shake the flask vigorously side to side in a reciprocating water bath at 130 cycles/ min for $2 \mathrm{~min}$. The goal of this step is to apply shear force to the lung minces, freeing the epithelial cells. The liquid in the flask should move in a back-and-forth fashion, rather than swirling. If liquid starts to swirl in the flask, stop shaking until the swirling stops before resuming shaking.

17. Filter the lung minces sequentially through filters pre-wetted with "Solution A" (see Subheading 2.1, item 18):

a. Nylon mesh, $100 \mu \mathrm{m}$.

b. Nylon mesh, $40 \mu \mathrm{m}$.

c. Nylon mesh, $20 \mu \mathrm{m}$.

Collect the filtered cells into $50 \mathrm{~mL}$ disposable beakers.

18. Let the filtering occur by gravity, using additional filters as needed when flow decreases due to filter clogging. We routinely use several separate filters for each of the $40 \mu \mathrm{m}$ and $20 \mu \mathrm{m}$ filter sizes in order to prevent the filters from clogging. When filters are clogged, the flow rates decrease. It should take less than 5 min to complete the pass through all three filter sizes.

19. From the cell suspension, remove $1 \mathrm{~mL}$ for measurement of viability, total cell count, and differential cell counts. At this stage of the cell isolation, representative yields and purities for each respective cell type should be the following: TI cells: $\sim 1 \times 10^{8}$ cells, $\sim 5 \%$ of which are TI cells; TII cells: $\sim 4 \times 10^{7}$ cells, of which $30-$ $50 \%$ are TII cells. Viabilities should be $>95 \%$ (see Note 1 ). Cell viability is assessed by the ability of cells to internalize and hydrolyze FDA. To a $100 \mu \mathrm{L}$ cell aliquot containing less than $1 \times 10^{5}$ cells add $0.2 \mu \mathrm{L}$ of FDA (see Subheading 2.1,

\footnotetext{
${ }^{1}$ As with all primary cell isolations, viabilities and purities of TI and TII cells can vary substantially among isolations. Therefore, it is important to assess the quality of the cell preparations used for the intended experiments and not to use cells with lower viabilities and purities than the threshold each investigator wishes to accept. Furthermore, if there are difficulties in the cell isolations, analysis of the cell yield and viability at successive steps is very useful in troubleshooting problems. We assess cell number, viability, and purity after filtering the mixed cell preparation (see Subheading 3.1, step 19) and also after cells have been purified prior to culture. Prolongation of the time of isolation and rough handling of tissues and cells are major causes of low viability. Surgical techniques should be practiced so that the lung perfusion takes less than $4 \mathrm{~min}$. Scissors should be new and/or recently sharpened to avoid shear stress on tissue and cells. Low purities after the initial enzymatic digests may be caused by inactive enzyme, omission of the initial step to lavage the lungs with elastase before instilling it, inadequate digestion times, or temperatures of instillate and/or water bath lower than $37^{\circ} \mathrm{C}$. Low purities after magnetic bead sorting should be further investigated after negative cell sorting to assess whether the negative sort is working properly. It is difficult to obtain high purities at the end of isolation if the purities are too low after the initial digestion.
} 
item 19). Incubate, shielded from light, for $20 \mathrm{~min}$ at room temperature and then wash the cells twice by centrifuging and resuspending the pellet in medium. Live cells will exhibit fluorochromasia.

20. Transfer the cell suspension to a $50 \mathrm{~mL}$ tube. For "magnetic sorting," add both rat and mouse IgGs to final concentrations of $50 \mu \mathrm{g} / \mathrm{mL}$. For "FACS sorting," add only rat $\mathrm{IgG}$ to $50 \mu \mathrm{g} / \mathrm{mL}$. From this point in the cell isolation protocol, use steriletechnique.

\subsection{Isolation of $\mathrm{TI}$ and TII Cells by Magnetic Sorting or FACS}

Two different separation techniques can be used to isolate either TI or TII cells from the cell suspension. Each method has its advantages and disadvantages. Magnetic sorting produces greater yields of cells, while FACS sorting produces cells of greater purity (see Table 1). These two techniques are described in the following three Subheadings.

3.2.1. Magnetic Separation of TI Cells from the Cell Suspension-Alveolar TI cells are isolated by depleting (negative selection) the crude cell suspension of TII cells and macrophages on a "coarse grade" separation column. This is followed by positive selection of TI cells on a "fine grade" separation column (see Subheading 2.1, item 24). During the column selection steps it is important not to allow the columns to run dry, which traps air in the column and diminishes the final cell yield.

1. Add $1 \mathrm{~mL}$ of monoclonal antibody supernatant against RTII- 70 (specific to TII cells) to the cell suspension from Subheading 3.1, step 20, mix gently, and incubate on ice for $5 \mathrm{~min}$. Dilute to $35 \mathrm{~mL}$ with "Solution A" containing 20\% FBS, and place a Percoll ${ }^{\mathrm{TM}}$ cushion $(150 \mu \mathrm{L})$ at the bottom of the centrifuge tube using a 9 in. glass Pasteur Pipet after adding the cell suspension to the tube (see Note 2). Centrifuge the cell suspension at $350 \times g$ for $15 \mathrm{~min}$ at $4^{\circ} \mathrm{C}$.

2. After centrifugation, remove and discard the supernatant above the pellet, add 200 $\mu \mathrm{L}$ of DNAse ( $2 \mathrm{mg} / \mathrm{mL}$ "Solution A"), and gently resuspend the pellet. Add 200 $\mu \mathrm{L}$ of goat anti-mouse IgG ferromagnetic beads (see Subheading 2.1, item 23) to the suspended cells and incubate for $10 \mathrm{~min}$ at $4^{\circ} \mathrm{C}$.

3. Pre-equilibrate a "coarse grade" syringe capture column with "Solution A" containing 20\% FBS attached to a three-way stopcock. Dilute the cell suspension to $2 \mathrm{~mL}$ with "Solution A" containing $20 \%$ FBS. Insert a 23 gauge needle at the tip of the column and place the column in the capture magnet's magnetic field, pass the cell suspension through the column five times, being careful not to let the column dry out (see Note 3). After the final pass, collect the unbound cells in a $15 \mathrm{~mL}$ centrifuge tube, add $20 \mu \mathrm{L}$ of purified IgG monoclonal antibody against RTI-40 ( 2 $\mu \mathrm{g} / \mathrm{mL}$ ), mix gently, and incubate on ice for $5 \mathrm{~min}$. Dilute to $15 \mathrm{~mL}$ with "Solution A" and add $\sim 150 \mu \mathrm{L}$ of Percoll ${ }^{\mathrm{TM}}$ to the bottom of the tube to act as a cushion. Centrifuge at $350 \times g$ for $15 \mathrm{~min}$ at $4^{\circ} \mathrm{C}$.

4. Remove the supernatant and add $200 \mu \mathrm{L}$ of DNAse ( $2 \mathrm{mg} / \mathrm{mL}$ "Solution A"), gently resuspend the pellet, and add $100 \mu \mathrm{L}$ of rat anti-mouse $\mathrm{IgG} 1$ ferromagnetic beads to the cell suspension. Incubate for $10 \mathrm{~min}$ on ice. Fit a "fine grade" syringe capture column with a 3-way stopcock and a 23 gauge needle, and pre-equilibrate

\footnotetext{
${ }^{2}$ To place a Percoll ${ }^{\mathrm{TM}}$ cushion at the bottom of the centrifuge tube, resuspend any cells that may have settled during the incubation period. With a 9 in. disposable sterile glass Pasteur Pipet, slowly place $\sim 150 \mu \mathrm{L}$ of Percoll ${ }^{\mathrm{TM}}$ at the bottom of the tube beneath the cell suspension.

${ }^{3}$ Columns are washed with ten bed volumes of "Solution A" prior to use. Care is taken not to introduce air or allow the column to dry during the entire procedure.
} 
the column with "Solution A" containing 20\% FBS. Place the column in the capture magnet's magnetic field. Dilute the cell suspension to $2 \mathrm{~mL}$ with "Solution A" containing $20 \%$ FBS, and pass the cell suspension through the column five times. After the final pass, wash the column five to eight times with "Solution A" containing $20 \%$ FBS (see Note 4). Remove the column from the magnetic field and collect the bound cells by back-washing $5 \mathrm{~mL}$ of buffer through the 3-way stopcock so that bound cells are collected from the top of the column bed. Collected TI cells are then centrifuged onto a Percoll ${ }^{\mathrm{TM}}$ cushion at $350 \times \mathrm{g}$ for $15 \mathrm{~min}$ at $4^{\circ} \mathrm{C}$, and resuspended in sterile culture medium.

3.2.2. Magnetic Separation of TII Cells from the Cell Suspension-Alveolar TII cells are isolated by depleting the cell suspension of TI cells and macrophages by negative selection on a "coarse grade" separation column, followed by positive selection of TII cells on a "fine grade" separation column.

1. Add $20 \mu \mathrm{L}$ of monoclonal antibody supernatant against RTI-40 (TI cell specific) to the cell suspension (see Subheading 3.1, step 20), mix gently, and incubate on ice for $10 \mathrm{~min}$. Dilute to $35 \mathrm{~mL}$ with "Solution A" containing 10\% FBS and centrifuge the cell suspension at $350 \times g$ for $10 \mathrm{~min}$ at $4^{\circ} \mathrm{C}$. After centrifugation, remove and discard the supernatant above the pellet, add $200 \mu \mathrm{L}$ DNAse $(2 \mathrm{mg} / \mathrm{mL}$ "Solution A"), and gently resuspend the pellet. Add $200 \mu \mathrm{L}$ of rat anti-mouse IgG1 and goat anti-rat IgG ferromagnetic beads and incubate on ice for $10 \mathrm{~min}$.

2. Fit a "coarse grade" syringe capture column with a 3-way stopcock and a 23 gauge needle and pre-equilibrate the column with "Solution A" containing 10\% FBS. Place the column in the capture magnet's magnetic field. Dilute the cell suspension to $2 \mathrm{~mL}$ with "Solution A" containing $20 \%$ FBS, and pass it through the column five times, being careful not to let the column dry out. After the final pass, collect the unbound cells in a $15 \mathrm{~mL}$ conical plastic centrifuge tube, add $1 \mathrm{~mL}$ of monoclonal antibody supernatant against RTII-70 (TII cell specific) to the cell, mix gently, and centrifuge at $350 \times \mathrm{g}$ for $10 \mathrm{~min}$ at $4^{\circ} \mathrm{C}$.

3. Remove the supernatant and add $200 \mu \mathrm{L}$ of DNAse ( $2 \mathrm{mg} / \mathrm{mL}$ "Solution A") to the cell pellet, gently resuspend it, and add $100 \mu \mathrm{L}$ of goat anti-mouse IgG ferromagnetic beads to the cell suspension. Incubate for $10 \mathrm{~min}$ on ice. Fit a "fine grade" syringe capture column with a 3-way stopcock and a 23 gauge needle and pre-equilibrate the column with "Solution A" containing 10\% FBS. Place the column in the capture magnet's magnetic field. Dilute the cell suspension to $2 \mathrm{~mL}$ with "Solution A" containing 20\% FBS and pass the cell suspension through the column five times. After the final pass, wash the column five times with "Solution A" containing $10 \%$ FBS. Collect the bound cells and centrifuge them at $350 \times g$ for 10 min at $4^{\circ} \mathrm{C}$.

3.2.3. Isolation of TI and TII Cells by Flow Cytometry-To isolate both cell types by flow cytometry, we differentially label both cell types with fluorescently labeled antibodies and sort the labeled cells on a flow cytometer.

1. Directly conjugate anti-RTI-40 to Alexa Fluor ${ }^{\circledR} 610-$ RPE using the Zenon technology (see Note 5). Approximately $3 \mu \mathrm{L}$ of anti-RTI-40 IgG1 $(1 \mathrm{mg} / \mathrm{mL})$ is labeled with $8 \mu \mathrm{L}$ of Zenon labeling reagent (see Subheading 2.2, item 2). The antiRTII-70 antibody is of the IgG3 subclass. Because the Zenon technology is not

\footnotetext{
${ }^{4} \mathrm{We}$ carefully monitor the wash buffer to make certain that unbound cells are not present in the wash buffer.

${ }^{5}$ Conjugate anti-RTI-40 to Alexa Fluor ${ }^{\circledR}$ 610-RPE 30 min before using.
} 
available for antibodies of the IgG3 subclass and because other methods of direct conjugation we have tried destroy the antigen binding capacity of anti-RTII-70, we use Alexa Fluor ${ }^{\circledR} 488$ anti-IgG3 as a secondary antibody for FACS sorting.

2. To the cell suspension from Subheading 3.1, step 20, add $1 \mathrm{~mL}$ of hybridoma supernatant containing anti-RTII-70 (see Subheading 2.1, item 22), incubate on ice for $10 \mathrm{~min}$, and centrifuge at $350 \times \mathrm{g}$ for $12 \mathrm{~min}$ at $4^{\circ} \mathrm{C}$ onto a $150 \mu \mathrm{L} \mathrm{Percoll}{ }^{\mathrm{TM}}$ cushion.

3. The supernatant liquid is removed and the centrifuge tube is tapped gently to dislodge the pellet. $50 \mu \mathrm{L}$ of DNAse ( $2 \mathrm{mg} / \mathrm{mL}$ "Solution A") is added directly to the pellet and the cells are gently resuspended in $1 \mathrm{~mL}$ of "Solution A" containing $20 \%$ FBS. The volume should be approximately $1.3 \mathrm{~mL}$.

4. Add a $100 \mu \mathrm{L}$ aliquot of suspended cells to three $15 \mathrm{~mL}$ disposable tissue culture tubes and label them "A," "B," and "C." Add $1 \mu \mathrm{L}$ of Alexa Fluor ${ }^{\circledR}$ 610-RPElabeled anti-RTI-40 to Tube "A," and add $0.5 \mu \mathrm{L}$ of goat anti-mouse IgG3-Alexa Fluor $^{\circledR} 488$ to Tube "B;" tube "C" receives no labeled antibodies. Tube " $C$ " serves as the unlabeled sorting control. The cells in these three tubes will be used to adjust the Alexa Fluor ${ }^{\circledR} 488$ and Alexa Fluor ${ }^{\circledR}$ 610-RPE FACS sorting gates. Transfer the remaining $1 \mathrm{~mL}$ of the cell suspension to a fourth $15 \mathrm{~mL}$ tube labeled "D," and add $10 \mu \mathrm{L}$ of Alexa Fluor ${ }^{\circledR} 610$-RPE-labeled anti-RTI-40 and $5 \mu \mathrm{L}$ of goat anti-mouse IgG3-Alexa Fluor ${ }^{\circledR} 488$. The TI cells will be labeled with Alexa Fluor ${ }^{\circledR}$ 610-RPE and the TII cells will be labeled with Alexa Fluor ${ }^{\circledR} 488$. Incubate at room temperature for $10 \mathrm{~min}$.

5. Dilute each tube to $15 \mathrm{~mL}$ with "Solution A" containing $20 \%$ FBS, add a $150 \mu \mathrm{L}$ Percoll $^{\mathrm{TM}}$ cushion to the bottom of each tube, and centrifuge at $350 \times g$ for $15 \mathrm{~min}$ at $4^{\circ} \mathrm{C}$.

6. Remove the supernatant from each of the pellets and add $50 \mu \mathrm{L}$ of DNAse $(2 \mathrm{mg} /$ $\mathrm{mL}$ "Solution A") to each of the pellets. Gently tap each tube to dislodge the pellet and resuspend each pellet in $0.5 \mathrm{~mL}$ of "Solution A" containing 20\% FBS. The cells are now labeled and ready for sorting. An aliquot of differentially labeled TI and TII cells in tube "D" should be checked for differential cell staining prior to sorting using a fluorescence microscope.

7. Dilute the cell suspensions in tubes "A," "B," and "C" to $0.5 \mathrm{~mL}$ with "Solution A" containing $20 \%$ FBS and filter them through a $20 \mu \mathrm{m}$ filter. Run the cells from tube "C" containing "unlabeled control cells" on the FACS to adjust the voltage. Then run labeled cells from tubes "A" and "B" and set the gates for Alexa Fluor ${ }^{\circledR}$ 610RPE- and Alexa Fluor ${ }^{\circledR}$ 488-labeled cells. Dilute the cells in tube "D" to a volume of $3 \mathrm{~mL}$, filter through a $20 \mu \mathrm{m}$ nylon mesh filter, and sort.

8. Sort the cells on a FACS Aria using a $100 \mu \mathrm{m}$ orifice and a slow flow rate (Aria flow rate setting " 3 "); this setting maximizes cell purity. (If an investigator desires to obtain greater number of cells at a cost of lower purities, higher flow rates can be selected.) Cells are sorted for $120 \mathrm{~min}$; collect sorted cells into a tube containing $0.5 \mathrm{~mL}$ FBS at $4^{\circ} \mathrm{C}$.

9. Cell sorting results are analyzed using $\mathrm{BD}^{\mathrm{TM}}$ Diva software.

AlveolarTIcellpuritiesaretypically $>98 \%$ byimmunofluorescence using anti-RTI-40 or anti-aquaporin 5 to identify TI cells; yields are $\sim 2.5 \times 10^{5}$ TI cells per rat.

Because TI cells are fragile, viability by FDA is lower, $~ 85-90 \%$ (see Subheading 3.1 , step 19), than that of TII cells. Type II cell purities are $>98 \%$ by immunofluorescence using anti-RTII-70 or anti-pro-SP-C as primary antibodies. 
Yields average $1.7 \times 10^{6} \mathrm{TII}$ cells per rat. TII cells have a viability of $>90 \%$ by Trypan blue exclusion. Substantially higher yields can be achieved with longer sorting times, but cell viability decreases with longer sorting periods.

3.2.4. Criteria for Identification of Alveolar Epithelial Cells-Cells are identified by assessing purities of cytocentrifuged cells with cell-specific antibodies, such as anti-RTI-40 and anti-aquaporin 5 for TI cells and anti-RTII-70 and anti-pro-SP-C for TII cells. For representative images of cytocentrifuged, stained cells at different stages of the cell isolation procedure, see Fig. 2a-f.

1. Preparation of cytocentrifuged cells: Cytocentrifuged preparations should be made at each step of the isolation. Dilute the cell suspension to $0.3 \times 10^{6}$ cells $/ \mathrm{mL}$. Make several ( 6) slides, using $\sim 0.3 \mathrm{~mL}$ of the cell suspension in each cytocentrifuge well. Centrifuge at $350 \times \mathrm{g}$ for $10 \mathrm{~min}$ at room temperature onto Superfrost Slides. The slides are then placed in a freshly made (daily) solution of $4 \%$ paraformaldehye/DPBS. Cell density should be adjusted as needed to achieve even distribution of individual cells on the slide; clumps of cells are difficult to count accurately.

2. To label cells with antibodies, remove the slides from fixative and rinse them five times with DPBS. Apply a ring of rubber cement with a $2 \mathrm{~cm}$ diameter around the sample. Pipet solutions onto the slide, but remove the solution by aspirating with a syringe and needle, taking care that the deposited cells do not dry out or are damaged. The procedure is as follows. Add blocking solution consisting of $10 \%$ serum (use the same serum type as the secondary antibody, which is usually goat serum) in DPBS to the slide and incubate the slide at room temperature for $1 \mathrm{~h}$. Rinse slides once with DPBS, add primary antibody diluted in blocking buffer, and incubate for $20 \mathrm{~min}$. Slides are then rinsed five times with DPBS, add secondary antibody diluted in blocking buffer, and incubate for $20 \mathrm{~min}$. Carefully remove the rubber cement ring by slowly "peeling" the ring from the slide using small forceps, rinse the slides ten times with DPBS once with water, and briefly air-dry. Add Prolong fixative, apply a coverslip, and seal the edges of the coverslip with nail polish. Allow the fixative to dry overnight in a light-protected environment (see Prolong protocol insert). Slides can be examined immediately or can be stored in a freezer.

\subsection{Culturing TI Cells}

TI cells are cultured on fibronectin-coated Transwells ${ }^{\circledR}$ under the following conditions:

1. Alveolar TI cells are cultured in DME-H16 containing $20 \%$ FBS and $50 \mu \mathrm{g}$ gentamicin/mL in 6-well tissue culture Transwell ${ }^{\circledR}$ plates previously coated with fibronectin, and maintained in a $10 \% \mathrm{CO}_{2} /$ air incubator at $37^{\circ} \mathrm{C}$.

2. To coat the inserts, use fibronectin isolated from bovine blood according to Engvall et al. (10). Dilute fibronectin to $100 \mu \mathrm{g} / \mathrm{mL}$ DPBS and filter the solution through a $0.2 \mu \mathrm{m}$ syringe filter; add $0.5 \mathrm{~mL}$ to each insert. After $3 \mathrm{~h}$ at room temperature, rinse each insert six times with DPBS at room temperature.

3. After isolating TI cells by magnetic sorting or FACS, centrifuge cells onto a Percoll ${ }^{\mathrm{TM}}$ cushion, $350 \times g$ for $15 \mathrm{~min}$ at $4^{\circ} \mathrm{C}$. Add $50 \mu \mathrm{L}$ of DNAse $(2 \mathrm{mg} / \mathrm{mL}$ "Solution A") to the cell pellet and carefully resuspend the cells in $0.5 \mathrm{~mL}$ of culture medium. Remove a small aliquot for measurement of cell yield, viability, and purity. Dilute the cell suspension to the desired density and plate onto the inserts (we seed cells at $1 \times 10^{4}$ cells/ $\mathrm{cm}^{2}$ ). Change the growth medium every 4 days. 


\subsection{Culturing TII Cells}

TII cells are cultured on EHS-coated Transwells ${ }^{\circledR}$ under the following conditions:

1. Alveolar TII cells are cultured in DMEM containing $1 \%$ rat serum, $10 \mathrm{ng} / \mathrm{mL}$ KGF (see Note 6), $10^{-4} \mathrm{M}$ 8-bromocyclic AMP, and $50 \mu \mathrm{g}$ gentamicin $/ \mathrm{mL}$ on EHS Matrix in a $10 \% \mathrm{CO}_{2} /$ air incubator at $37^{\circ} \mathrm{C}$.

2. Coat Transwell ${ }^{\circledR}$ inserts with $0.5 \mathrm{~mL}$ of EHS Matrix diluted 2:1 with DMEM. Slowly thaw the EHS Matrix on ice and DMEM at $4^{\circ} \mathrm{C}$; immediately use the solution to coat each insert. Polymerization of the matrix is initiated by warming the gels to $37^{\circ} \mathrm{C}$ in an incubator.

3. Centrifuge the isolated TII cells at $350 \times g$ for $10 \mathrm{~min}$ at $4^{\circ} \mathrm{C}$.

4. Add $50 \mu \mathrm{L}$ of DNase ( $2 \mathrm{mg} / \mathrm{mL}$ "Solution A") to the cell pellet and carefully resuspend the cells in $1.0 \mathrm{~mL}$ of culture medium. Remove a small aliquot for measurement of cell purity, viability, and yield.

5. Dilute TII cells to the desired density (we seed cells at $2 \times 10^{5}$ cells $/ \mathrm{cm}^{2}$ ) and plate on the EHS Matrix-coated Transwell ${ }^{\circledR}$ plates; change the medium every 4 days.

\section{Acknowledgments}

We wish to thank Lennell Allen for the electron micrograph and preparation of the figures. This work was supported by NIH Grants 5RC1HL099820 and HL-24075.

\section{References}

1. Mercer RR, Russell ML, Roggli VL, Crapo JD. Cell number and distribution in human and rat airways. Am J Respir Cell Mol Biol. 1994; 10:613-624. [PubMed: 8003339]

2. Stone KC, Mercer RR, Gehr P, Stockstill B, Crapo JD. Allometric relationships of cell numbers and size in the mammalian lung. Am J Respir Cell Mol Biol. 1992; 6:235-243. [PubMed: 1540387]

3. Dobbs LG, Johnson MD. Alveolar epithelial transport in the adult lung. Respir Physiol Neurobiol. 2007; 159:283-300. [PubMed: 17689299]

4. Dahlin K, Mager EM, Allen L, Tigue Z, Goodglick L, Wadehra M, Dobbs L. Identification of genes differentially expressed in rat alveolar type I cells. Am J Respir Cell Mol Biol. 2004; 31:309-316. [PubMed: 15205179]

5. Gonzalez RF, Allen L, Dobbs LG. Rat alveolar type I cells proliferate, express OCT-4, and exhibit phenotypic plasticity in vitro. Am J Physiol Lung Cell Mol Physiol. 2009; 297:L1045-L1055. [PubMed: 19717550]

6. Dobbs LG. Isolation and culture of alveolar type II cells. Am J Physiol. 1990; 258:L134-L147. [PubMed: 2185652]

7. Dobbs LG, Gonzalez R, Williams MC. An improved method for isolating type II cells in high yield and purity. Am Rev Respir Dis. 1986; 134:141-145. [PubMed: 3637065]

8. Dobbs, LG.; Gonzalez, RF. Isolation and culture of pulmonary alveolar epithelial type II cells. In: Freshney, RI.; Freshney, MG., editors. Culture of epithelial cells. 2. Wiley-Liss; New York, NY: 2002. p. 277-303.

9. Dobbs LG, Mason RJ, Williams MC, Benson BJ, Sueishi K. Secretion of surfactant by primary cultures of aleveolar type II cells isolated from rats. Biochim Biophys Acta. 1982; 713:118-127. [PubMed: 6215948]

10. Engvall E, Ruoslahti E. Binding of soluble form of fibroblast surface protein, fibronectin, to collagen. Int J Cancer. 1977; 20:1-5. [PubMed: 903179]

\footnotetext{
${ }^{6}$ Do not filter the KGF through a $0.2 \mu \mathrm{m}$ filter, as most activity will be lost.
} 


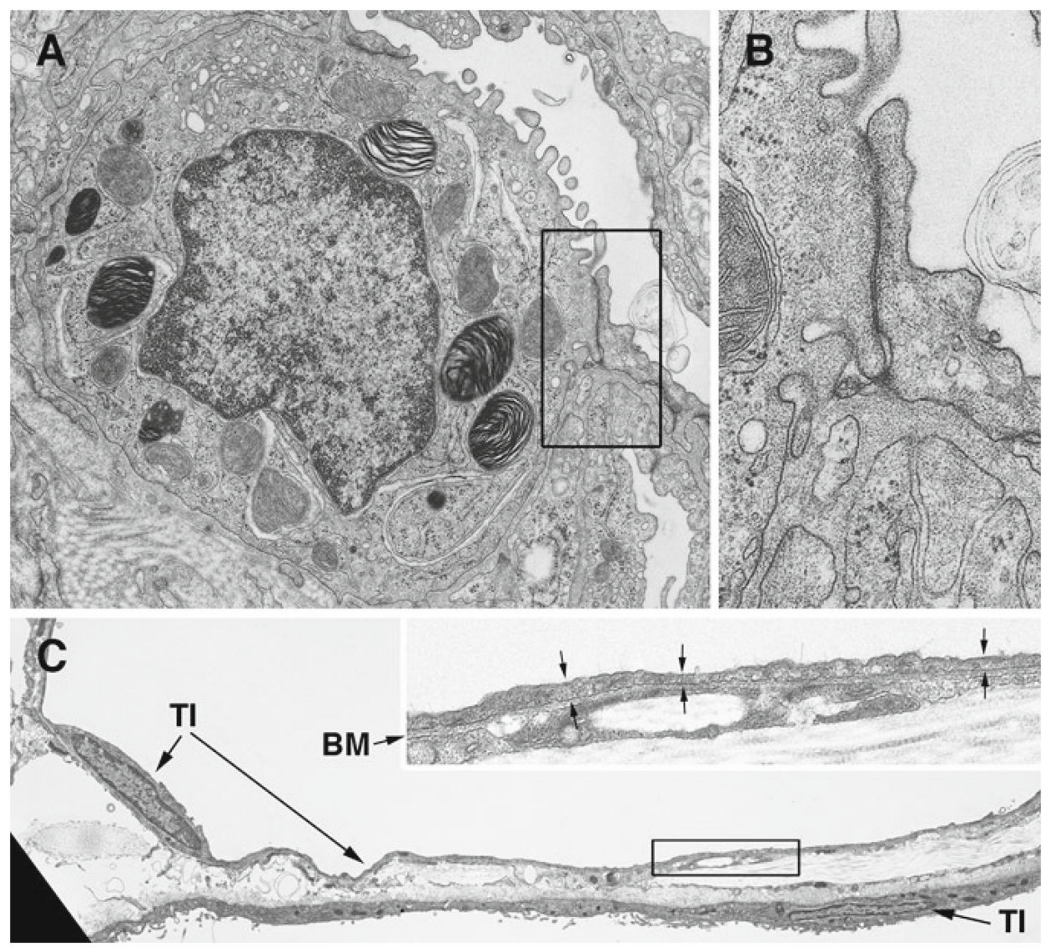

Fig. 1.

Electron micrograph showing TI and TII cells. (a) Rat TII cells with electron-dense lamellar bodies. The box contains a junction between a TI cell and an adjacent TII cell. (b ) Higher magni fication of the image within the box in panel (a), illustrating the tight junction between the two cell types. (c) A portion of a rat TI cell showing the nucleus and a portion of the thin cytoplasmic extension (TI, large arrows ) overlying the interstitial. Extensions of a different TI cell can be seen on the other side of the interstitium. A portion of the nucleus is visible (TI, arrow, lower right). The box and higher magnification (inset) view show the very thin cytoplasmic extensions of the TI cell on the basement membrane (BM) that separates the TI cell and the interstitial compartment (electron micrographs courtesy of Lennell Allen, C.V.R.I., U.C.S.F.). 

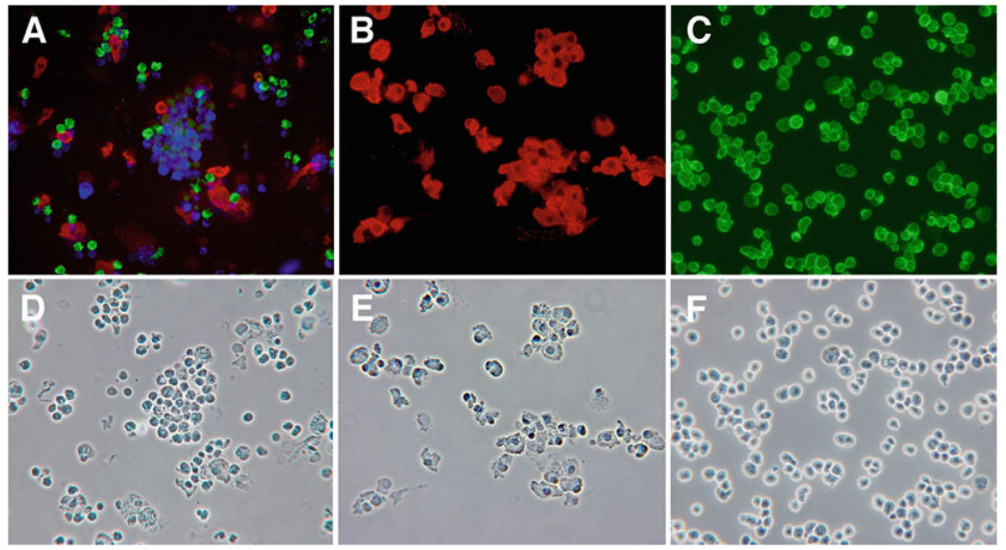

Fig. 2.

Cytocentrifuged preparations of cells at different stages of the cell isolation procedure. The images shown are paired immunofluorescence $(\mathbf{a}, \mathbf{b}, \mathbf{c})$ and phase contrast $(\mathbf{d}, \mathbf{e}, \mathbf{f})$ views of cytocentrifuged preparations. Cells are stained for CC10 (blue, Clara cells+), RTI-40 (red, TI cells+), and RTII-70 (green, TII cells+) (a,d ): Crude cell digest (Subheading 3.1, step 19). (b, e): FACS sorted TI cells. (c, f): FACS sorted TII cells. 


\section{Table 1}

Comparison of yields and purities of TI and TII cells isolated by either ferromagnetic beads or FACS (mean $\mathrm{SD}, n=10)$

\begin{tabular}{lll} 
Isolation method & Cell yield & Cell purity \\
\hline Magnetic sorting of TI cells & $8.9 \pm 2.6 \times 10^{6}$ & $80-91 \%$ \\
\hline Magnetic sorting of TII cells & $21.0 \pm 3.8 \times 10^{6}$ & $84-92 \%$ \\
\hline FACS isolation of TI cells & $2.5 \pm 0.5 \times 10^{5}$ & $>98 \%$ \\
\hline FACS isolation of TII cells & $1.7 \pm 0.7 \times 10^{6}$ & $>98 \%$ \\
\hline
\end{tabular}

TI and TII cells isolated by FACS have a greater purity, but lower yields 